Download

UDC 779.85

https://doi.or

$\mathrm{g} / 10.17721 / 2308-135 X .2020 .57 .17-25$

Vyshnevskyi Viktor Ivanovych,

Doctor of geography sciences, professor National Aviation University, Kyiv, Ukraine, ,e-mail:vishnev.v@gmail.com

\title{
CHERNOHIRSKYI TRAIL AS A BRAND OF UKRAINIAN HIKING TOURISM
}

Aim: promotion of the walking route by the Chornohora Ridge of the Ukrainian Carpathians in the section from Hoverla to Pip Ivan mountain.

Methods: observation, measurement, description, comparison, analysis, analogy, cartographic, statistical. Based on radar survey data SRTM and Global Mapper program it was created a three-dimensional image of the studied region. The SAS.Planet program was used to measure distances.

Results: A three-dimensional image of the Ukrainian Carpathians was created using SRTM data. The main information about the highest Chornohirskyi Ridge in these mountains was presented. The route from Hoverla to Pip Ivan mountain is described. It is proposed to call it the Chernohirskyi Trail. Data on the height of the terrain at the beginning and end of the route are shown. A brief description of the tourist attractions on the trail is provided, including lakes Nesamovyte and Brebeneskul. Information on the meteorological and at the same time astronomical observatory "White Elephant", which was built on the eve of the Second World War was presented. Modern measures for its restoration are described, in particular as to installation of an automated meteorological station on its roof. Based on observations on nearby 
meteorological stations, the climatic conditions on the route were identified. Data about air temperature in January and in the warm period of the year are presented. The features of air temperature changes, depending on elevation, are established. Data on the amount of precipitation at existing meteorological stations in the mountains are provided. Information on the height of snow cover was presented. The features of snow formation and its disappearance in the southeastern part of the Ukrainian Carpathians are shown.

Scientific novelty. The hiking route by the Chornohora Ridge of the Ukrainian Carpathians is substantiated as brand of Ukrainian hiking tourism. The expediency of traffic from Hoverla to Pip Ivan has been proved. It was found that at altitudes above $1000 \mathrm{~m}$ the decrease in air temperature in July is $0.40 \square \mathrm{C}$ per $100 \mathrm{~m}$ altitude, in August $-0.30 \square \mathrm{C}$ per $100 \mathrm{~m}$. It is substantiated that the best time to travel along the Chornohirskyi Ridge is August. The significant distribution of snow cover on the Chornohirskyi Ridge, which is the highest within the Ukrainian Carpathians, is shown.

Practical significance: popularization of tourism in the Ukrainian Carpathians, providing tourists with information to make travel more interesting and safe.

Keywords: trail, Chornohora, Hoverla, Pip Ivan, lake, observatory, air temperature.

References:

1. Vyshnevskyi V.I. Ecological tourism. Textbook. Kyiv: Interpress LTD, 2015. 140 p.

2. Gabchak N.F. Meteorological observatory on Pip Ivan mountain as a tourist object of the Chornohirskyi massif // Proceedings of the Military Institute of Taras Shevchenko National University of Kyiv. Kyiv: WIKNU. 2011. Issue 33. P. 322-330. 
3. Kostiv L.Ya., Melnyk A.V., Karabinyuk M.M., Melnyk Yu.V. Long-term meteorological observations in the wooded middle mountains of the Prut River basin within the Chornohora landscape / Proceedings of the International Scientific Seminar Dedicated to the 75th Anniversary of B.P. Mukha's Birth and the 50th Anniversary of the Roztotsk Landscape and Geophysical Base of Lviv University named after Ivan Franko (Lviv-Bryukhovychi, May 10-12, 2019). Lviv: Ivan Franko Lviv National University, 2019. P. 17-21.

4. Мельник A.B. Ukrainian Carpathians: ecological and landscape research. Lviv: Published center of Ivan Franko Lviv National University, 1999. 246 p.

5. Mikitchak T.I., Rozhko I.M., Lenko O.V. Physico-geographical and hydrochemical characteristics of lakes and lakes of the Chornohora massif (Ukrainian Carpathians) // Proceedings of UkrRHMl. 2020. Issue 259. P. 231-244.

6. Sktynnyk O.V. The first results and prospects of meteorological observations on the Pip Ivan mountain // Bulletin of Taras Shevchenko National University of Kyiv. Geography series. 2019. Issue 74. P. 82-88.

7. Smirnov I.G., Rykychynska A.F. "White Elephant" in the Ukrainian Carpathians: recreational and tourist potential // Geography and Tourism. 2019. Issue 44. P. 44-58. 
8. Yamalov O. Trails of the Carpathians. Guidebook. Kharkiv: Folio, 2019. 512 p.

9. www.glovis.usgs.gov - US Geological Survey website.

Надійшла до редколегії 17.08.2020 